\title{
Analysis of Labor Needs at Perawang Port 2013 - 2018
}

\author{
${ }^{1}$ Royandi, ${ }^{2}$ Harlen, ${ }^{3}$ Any Widayatsari \\ ${ }^{1}$ Master Student at the Department of Economics and Business, Universitas Riau, Indonesia \\ ${ }^{2}$ Professor of the Department of Ekonomics and Business, Universitas Riau, Indonesia \\ ${ }^{3}$ Doctoral of the Department of Ekonomics and Business, Universitas Riau, Indonesia \\ e-mail: royandiharbor@gmail.com
}

\begin{abstract}
Shipment of container has become a phenomenon in the world of logistics it is seen as more efficient and effective means of transportation. Changes in shipment patterns from break bulk cargo to containers also occur in the port of Perawang along with the construction of bridges in Siak Sri Indrapura so that large vessels can no longer enter and carry out loading and unloading activities at the Perawang port, and this has resulted in companies having to invest in mechanical equipment because ships that enters the perawang private jetty is no longer supported by the crane on the ship.

Based on data owned by PT. Indah Kiat Perawang container shipments continue to increase from year to year but not accompanied by an increase in the number of labor. This study aims to see the effect of Container Shipment, Mechanical Equipment Investment and Labor Wages on Labor Demand at perawang port. This study uses secondary data with data from 12 semesters from 2013 to 2018. With independent variables namely Container Shipment, Investment and Wages. The analysis technique used is multiple regression. The results of the research shows that container shipment and investment has no significant effect on labor demand, whilts wages has a significant and negative effect on labor demand
\end{abstract}

Keywords: Shipment container, Investment, Wages and Labor demand.

Pengapalan kontainer telah menjadi fenomena di dunia logistik yang dipandang sebagai sarana transportasi yang lebih efisien dan efektif. Perubahan pola pengiriman dari kargo curah ke kontainer juga terjadi di pelabuhan Perawang bersamaan dengan pembangunan jembatan di Siak Sri Indrapura sehingga kapal-kapal besar tidak dapat lagi masuk dan melakukan kegiatan bongkar muat di pelabuhan Perawang, dan ini memiliki mengakibatkan perusahaan harus berinvestasi dalam peralatan mekanik karena kapal yang memasuki dermaga pribadi perawang tidak lagi didukung oleh crane di kapal.

Berdasarkan data yang dimiliki oleh PT. Pengiriman kontainer Indah Kiat Perawang terus meningkat dari tahun ke tahun tetapi tidak disertai dengan peningkatan jumlah tenaga kerja. Penelitian ini bertujuan untuk melihat pengaruh Pengiriman Kontainer, Investasi Peralatan Mekanik dan Upah Tenaga Kerja terhadap Permintaan Tenaga Kerja di pelabuhan perawang. Penelitian ini menggunakan data sekunder dengan data dari 12 semester 2013-2019. Dengan variabel independen yaitu Pengiriman Kontainer, Investasi dan Upah. Teknik analisis yang digunakan adalah regresi berganda. Hasil penelitian menunjukkan bahwa pengiriman kontainer dan investasi tidak berpengaruh signifikan terhadap permintaan tenaga kerja, sedangkan upah upah memiliki pengaruh signifikan dan negatif terhadap permintaan tenaga kerja.

Kata Kunci : Pengiriman kontainer, Investasi, Upah, Tenaga Kerja. 


\section{INTRODUCTION}

Indonesia is the largest archipelago country in the world with a beach length of $95,181 \mathrm{Km}$, 17,504 islands and sea area of 5.8 Million Km2. This was also reaffirmed in Article 25 of the 2nd Amendment to the 1945 Constitution (Kusumastanto, 2018). With this condition, the port industry in Indonesia should grow better and provide Port economics multiplier effects or smooth distribution that is able to contribute to the country's revenue in the form of regional industrial sector growth, tax revenue and job creation (Sudarmo, 2018). In accordance with the development of container shipments continue to increase in Indonesia, this can be seen from Figure 1 below:

Figure 1: Container Port Throughput 2011 - 2018 (Indonesia)

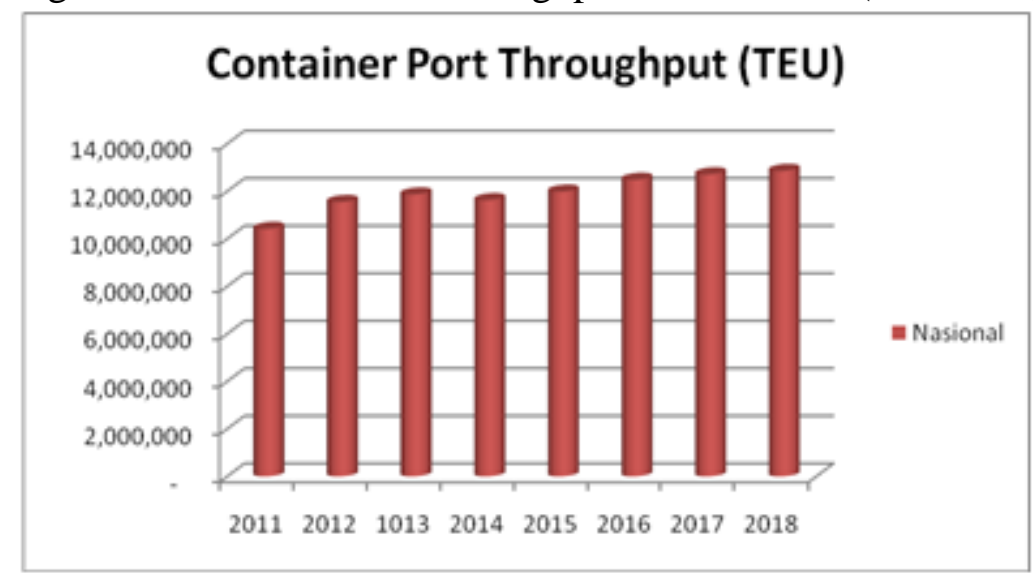

Source: UNCTADstat, 2019

This also applies at the port of PT. Indah Kiat Perawang along with the increase in production results and changes in the pattern of shipments as impact of the Siak bridge construction. Amid the high cost of logistics and international market competition, companies always try to reduce costs so that the products produced can compete in the market, for that the company must do efficiency. This is because the cost of rental equipment and labor costs always increase. However, the high volume of loading and unloading is not accompanied by an increase in the needs of labors, where the needs for labors tend to continue to decrease even though the number of available manpower tends to remain constant (416 people: KTKBM data for 2019). We can see this in Figure 2 below:

Figure 2 : Comparison of the Increase in Loading and Unloading Volume with the Number of Labors Demands in Perawang Port 2011 - 2018

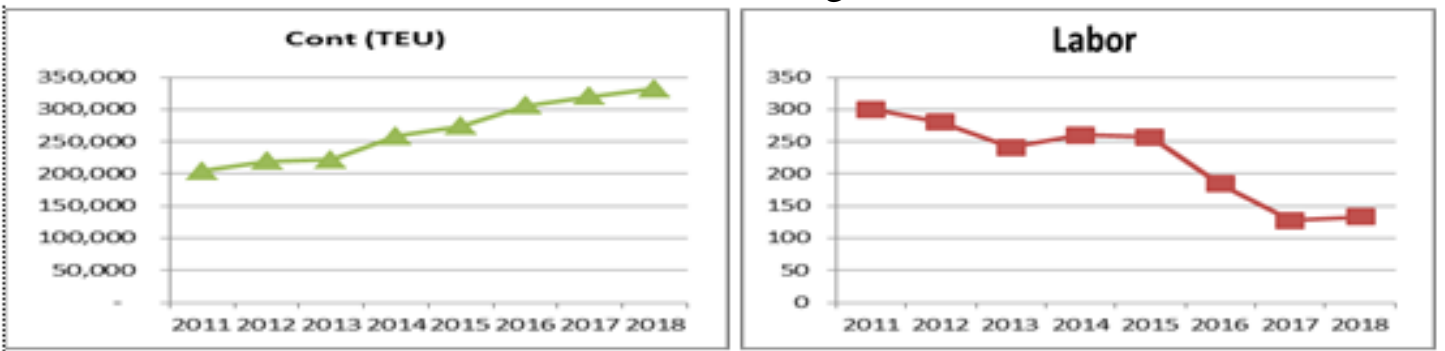

Source : PT. Indah Kiat, 2019

From Figure 2 above, there is a contrast between the increase in shipments as the output of a port and the fluctuating and tending needs of labors which tend to decrease. This condition is contrary to the 
theory of production that if output increases, the number of labors also increases. To speed up the loading and unloading process at the port, the companies invest more cranes to make time efficient. From the investment data carried out by companies in the past 6 years, investment fluctuations are quite sharp and tend to decrease every year, this can be seen in Figure 3 below:

Figure 3: Investment Value of Cranes and Wages at Perawang Port 2013 - 2018 (Rupiah)

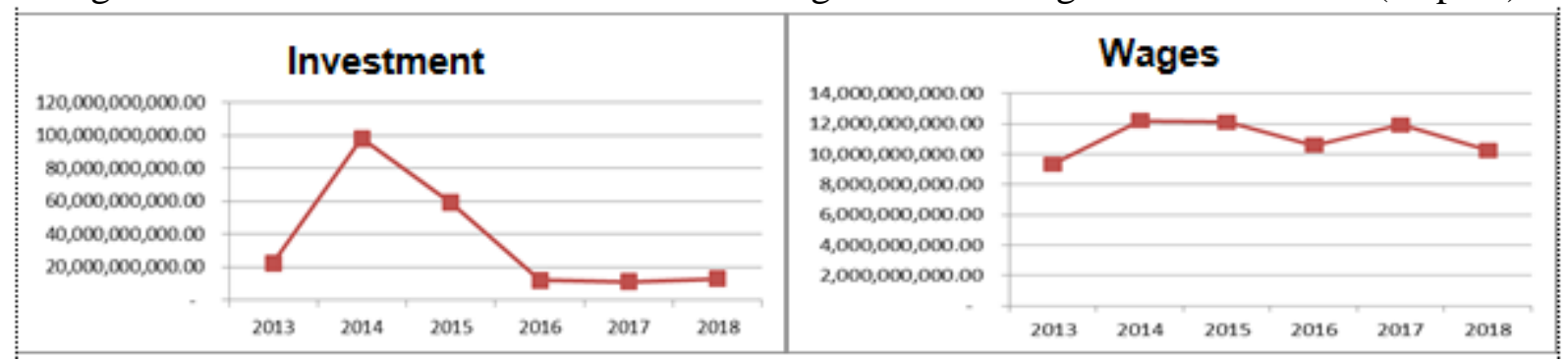

Source : PT. Indah Kiat, 2019

The decrease in labor needs does not reduce the costs that companies must incur for labors, although the need for the number of labors needed to work decreases but labor costs incurred by companies continue to fluctuate and tend to increase.

Based on the explanation above, the purpose of this study is to analyze the variable shipment container (output), investment and wages to the demand for the number of labors at the Port of Perawang in 2013 - 2018.

\section{METHOD}

\subsection{Data}

In this study the data used are secondary data in the form of time series data for all variables, namely Labor Demand, Container Shipment, Mechanical Equipment Investment, and Labor Wages. This secondary data was obtained from the annual port operational report (TUKS) of PT. Indah Kiat Pulp \& Paper Tbk - Perawang for 12 semesters from 2013 to 2018.

\subsection{Operational Definition of Variable}

The scope of this study includes the factors that influence the demand for labor in the port (TUKS) of PT. Indah Kiat Pulp \& Paper Tbk - Perawang viewed from the perspective of increasing container shipments, mechanical equipment investment and labor costs during the 12 Semester period from 2013 to 2018. To further facilitate the discussion the authors limit the research variables, to:

1. Demand for workers is the laborers needed at the port of PT. IKPP - Perawang for loading and unloading activities, and this variable is counted in the number of people.

2. Container Shipment is the number of containers entering and leaving the port of PT. Indah Kiat Pulp \& Paper Tbk - Perawang in TEU (Twenty Equivalent Unit).

3. Mechanical Equipment Investment is the value of Crane investment needed for the operation of loading and unloading of goods and containers at the port of PT. Indah Kiat Pulp \& Paper Tbk Perawang both for rental and company-owned assets, and this variable is calculated in units of Rupiah (an average of 6 months).

4. Labor wages are wages paid by companies to loading and unloading labors (KTKBM) at the port of PT, Indah Kiat Pulp \& Paper - Perawang based on labor results and are valued in cash (Rupiah) per labor per month. 


\subsection{Data Analysis Method}

Data analysis conducted was quantitative analysis expressed by numbers and calculations using statistical methods assisted by the Eviews program. Analysis of the data used in this study is testing classic assumptions, multiple regression analysis and hypothesis testing. The form of the multiple linear regression equation is as follows:

$\mathrm{Y}=\mathrm{a}+\mathrm{b} 1 \mathrm{x} 1+\mathrm{b} 2 \times 2+\mathrm{b} 3 \times 3+\mathrm{e}$

Remarks :

Y = Dependent Variable of Labor Demand (Person)

a $\quad$ Constanta

b1-b3 = Independent variable regression coefficient

$\mathrm{x} 1=$ Independent Variable Container Shipment (TEU)

$\mathrm{x} 2=$ Independent Variable of Mechanical Equipment Investment (Rupiah)

x3 = Independent Variable Labor Wage (Rupiah)

e $\quad=$ Error Term

\subsection{Classical Assumption Deviation Test}

To avoid bias and errors in data processing, the following classic assumption tests are needed:

a. Normality test aims to test whether this multiple linear regression model has a normal distribution or not.

b. Multicollinearity test is done to test whether the regression model found a relationship between independent variables

c. The heteroscedasticity test is used to test whether a regression model of variation occurs from one observation to another.

d. The autocorrelation test is used to test whether there is a correlation between the disturbance error in the t period and the error in the previous t-1 period.

\subsection{Coefficient of DeterminationTest $\left(\mathbf{R}^{2}\right)$}

The coefficient of determination states the proportion or percentage of the total variation of the dependent variable explained by the independent variable

\subsection{T Statistics Test}

$\mathrm{T}$ test is used to determine the effect of variable (partial) or each independent variable on the dependent variable.

\section{F Statistics Test}

$\mathrm{F}$ test is used to determine the effect simultaneously or together of independent variables on the dependent variable. 


\section{FINDING AND DISCUSSION}

\subsection{Classical Assumption Test}

\section{Normality Test}

Figure 5: Normality Test

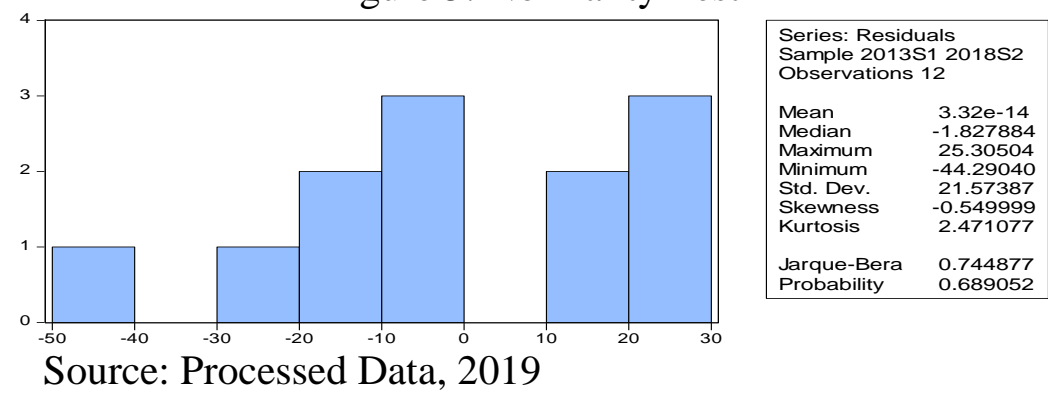

In the above data, the probability value is $0.689052>0.05$ so it can be concluded that the data used are normally distributed.

\section{Multicollinearity Test}

Table 1: Multicollinearity Test

\begin{tabular}{cccc}
\hline \hline Variable & $\begin{array}{c}\text { Coefficient } \\
\text { Variance }\end{array}$ & $\begin{array}{c}\text { Uncentered } \\
\text { VIF }\end{array}$ & $\begin{array}{c}\text { Centered } \\
\text { VIF }\end{array}$ \\
\hline \hline CONTAINER & $3.99 \mathrm{E}-07$ & 156.2791 & 2.804981 \\
INVESTMENT & $4.03 \mathrm{E}-18$ & 1.891554 & 1.215830 \\
WAGES & $4.68 \mathrm{E}-11$ & 26.98668 & 3.044747 \\
C & 4638.555 & 86.97712 & NA \\
\hline \hline
\end{tabular}

Source: Processed Data, 2019

The calculation results of the data analysis above, obtained Centered VIF values for all independent variables <10. Based on these results it can be concluded that the regression model is free from multicollinearity.

\section{Autocorrelation Test}

Table 2: Autocorrelation Test

\begin{tabular}{llll}
\hline \hline F-statistic & 0.277821 & Prob. F(2,6) & 0.7667 \\
Obs*R-squared & 1.017094 & Prob. Chi-Square(2) & 0.6014 \\
\hline \hline
\end{tabular}

Source: Processed Data, 2019

Based on the data it can be seen that the probability value of Obs * R-squared is 0.6014 (Prob.> 0.05), so it can be concluded that the equation model does not experience autocorrelation problems. 


\section{Heteroscedasticity Test}

Table 3 : Heteroscedasticity Test

\begin{tabular}{llll}
\hline \hline F-statistic & 2.840389 & Prob. F(3,8) & 0.1057 \\
Obs ${ }^{2}$-squared & 6.189272 & Prob. Chi-Square(3) & 0.1028 \\
Scaled explained SS & 2.023310 & Prob. Chi-Square(3) & 0.5676 \\
\hline \hline
\end{tabular}

Source: Processed Data, 2019

From the data above we get the value of Obs * $\mathrm{R}$-Squared and Chi Squares value. If Obs * $\mathrm{R}$ Squared is above the value of Chi Squares, and the probability of Chi Squares value of 0.1028>0.05 indicates there is no heteroscedasticity in the model.

\section{Statistics Test \\ Simultaneous Test (F Test)}

Table 4 : Estimation Result

\begin{tabular}{lrll}
\hline \hline R-squared & 0.891588 & Mean dependent var & 197.0833 \\
Adjusted R-squared & 0.850933 & S.D. dependent var & 65.52232 \\
S.E. of regression & 25.29761 & Akaike info criterion & 9.560498 \\
Sum squared resid & 5119.752 & Schwarz criterion & 9.722134 \\
Log likelihood & -53.36299 & Hannan-Quinn criter. & 9.500655 \\
F-statistic & 21.93083 & Durbin-Watson stat & 2.497078 \\
Prob(F-statistic) & 0.000325 & & \\
\hline \hline
\end{tabular}

Source: Processed Data, 2019

From the table above it can be seen that the calculated $\mathrm{F}$ value of 21.93083 at the significance level of 0.000325 , because the probability value $<0.05$, it can be concluded that together the shipment, investment and labor costs affect the number of labors.

\section{Partial Test (T Test)}

Table 5 : T Test Results

\begin{tabular}{crrrr}
\hline \hline Variable & Coefficient & Std. Error & t-Statistic & Prob. \\
\hline \hline CONTAINER & -0.000416 & 0.000631 & -0.658617 & 0.5286 \\
INVESTMENT & $3.63 \mathrm{E}-09$ & $2.01 \mathrm{E}-09$ & 1.809871 & 0.1079 \\
WAGES & $-2.41 \mathrm{E}-05$ & $6.84 \mathrm{E}-06$ & -3.528747 & 0.0077 \\
$\mathrm{C}$ & 371.8963 & 68.10694 & 5.460476 & 0.0006 \\
\hline \hline
\end{tabular}

Source: Processed Data, 2019

Of the 3 variables tested partially that have a significant influence on the needs of labors are the variable labor wages with a negative influence with a t-statistic value of -3.528747 and a probability of 0.0077 smaller than the alpha value that we used in this study that is 0.05 . This means that the higher the wage, the lower the demand for labor. For container shipment and investment variables, no significant effect on labor demand. 


\section{Coefficient of Determination $\left(\mathbf{R}^{2}\right)$}

From Table 4 above shows that the value of $\mathrm{R}$ Square is 0.891588 . This means that the contribution of shipments, investments and labor costs to total labor demand is $89.1588 \%$ while the remaining $10.8412 \%$ is influenced by other variables not included in this research model.

\section{Discussion}

\section{Effect of shipment on the number of labors}

Changes in product shipments from breakbulk systems to containers have had an impact on work processes and labor needs. In the shipping or shipment process, PT. Indah Kiat Pulp \& Paper Tbk Perawang still uses 2 shipping methods for its products (pulp, paper and tissue), namely breakbulk and container. Based on the data of the last 6 years, pulp products which used to use a breakbulk system gradually changed to using containers. We can see the decrease in shipment pulp breakbulk from the data in Figure 6 below:

Figure 6: Break-bulk Pulp Product Shipment 2013 - 2018

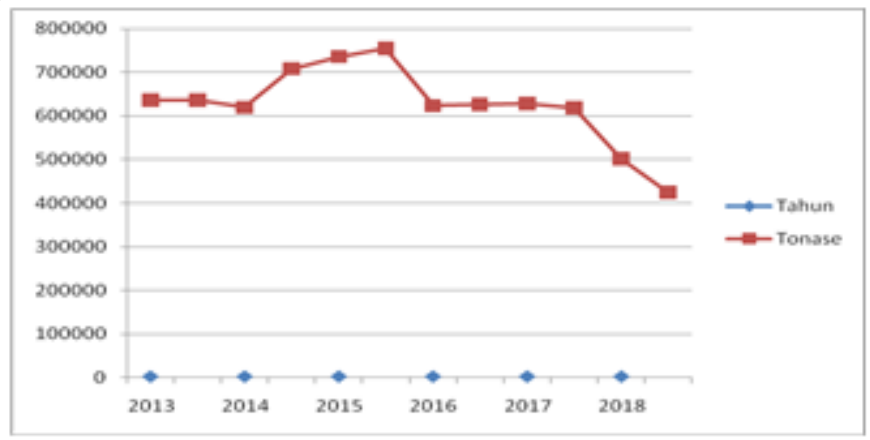

Source: PT. IKPP, 2019

Changes in shipping patterns and the decrease in shipment break-bulk certainly also affect the number of break-bulk ship call to PT. Indah Kiat Pulp \& Paper Tbk - Perawang as shown in the following processed data in Figure 7:

Figure 7: Average call of break-bulk (pulp) ship in 2013 - 2018

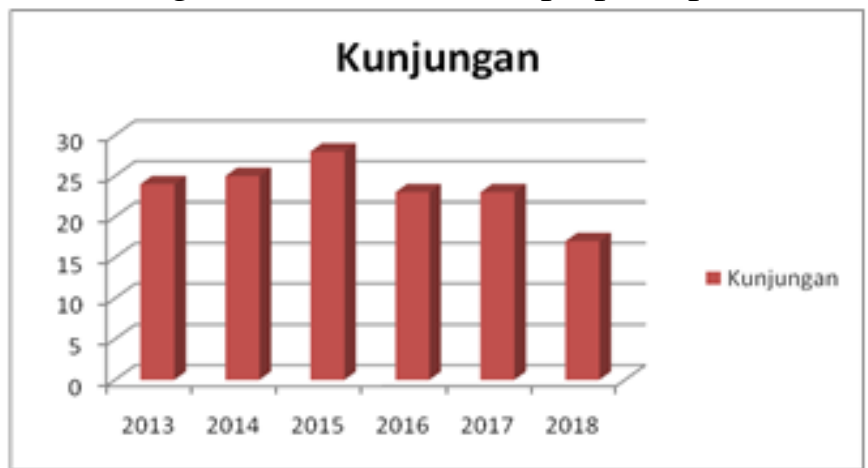

Source: PT. IKPP, 2019

The reduction in ship call and loading with the break-bulk system results in reduced work that can be done by labors. For every product shipped using the break-bulk system, 11 laborers are required for each shift (laborers use 2 shifts, morning and night shifts), in total means for 1 ship used 22 labors or adjusted to the number of cranes used. And if shipping uses containers the number of labors used is a maximum of 7 people / shift / ship or can be less depending on the type of crane used. The number of 
laborers used is based on company work agreements with Stevedoring Company (PBM) and based on a joint decision of the Director General of Sea Transportation, the Director General of Labor Supervision and Deputy of the Institutional Sector of Cooperatives and Small and Medium Enterprises on the Development and Arrangement of Unloaded Labors (TKBM) at Ports states that the number of TKBM work groups placed in each terminal must be adjusted to the type of goods and the volume of goods loading and unloading activities, this is in accordance with Monaco \& Olsson's (2005) study, which says that what determines the needs of labors is the ability of labor organizations to negotiate with consumers or service users instead of container output. The results of this study support the research of Tomlinson (2009) which in his research said that the use of containers has a negative impact on the use of the number of labors because the goods are already loaded in containers and easier to handle.

This condition is different from the research by Ismail et al (2013) which states that output has a positive and significant effect on labor demand and hence the increase in output / production also increases the amount of labor employed. Research by Mahendra (2014) also contradicts the results of this study because in his research concluded that production capacity has a positive effect on employment. It is different from what happened at Perawang Port where the influence of container shipments tends to be negative, although not significant. This is the same as Riky Hasnedi's research (2012) which concluded that output does not have a significant effect due to the use of technology used by industry, so that the work that humans should be doing is replaced by machines which causes low labor demand even though the resulting output is higher. This condition can be proven by changing the shipment to the container, so the handling of cargo in the unit of goods is getting smaller because the cargo has become one in the container.

\section{Effect of investment on the number of labors}

From the existing data, investments made by companies based on the processing of e-views systems actually have an impact on increasing demand for the number of labors who work. The current conditions of the types of cranes used at Perawang port are as follows:

Table 6: Types and Number of Crane Units of PT. Indah Kiat Pulp \& Paper - Perawang

\begin{tabular}{|c|c|c|c|}
\hline No & Type Crane & Total & Remarks \\
\hline 1. & Gantry Crane & 3 & Special for container \\
\hline 2. & Jib Crane & 3 & Multi purpose \\
\hline 3. & Crawler Crane & 4 & Mostly for breakbulk cargo \\
\hline \multicolumn{2}{|c|}{ Total } & 10 & \\
\hline
\end{tabular}

Source: PT. IKPP, 2019

The results of this study contradict the research conducted by El-Sahli \& Upward (2017) which in his research said that changes in container shipments and investment in supporting technology have an impact on reducing labor work. This condition is caused by the pattern of shipments at Perawang Port that still does not fully use containers as a product distribution tool so that the company's investment is still focused on how the equipment that is leased or purchased can be multifunctional and can be used optimally and does not result in waste because many standby waits for cargo, this resulting in mechanical equipment that is rented is still mostly a crawler crane which if used for container loading still uses labor on each unit to install and open slings when the container will be loaded or unloaded onto the ship or vice versa. 
This study supports the results of previous studies conducted by Divianto (2014), Chusna (2013), Putra (2012), Indarti (2016), Ningsih (2015), which states that capital / investment has a positive and significant effect on employment due to new investments or tools will require additional labor.

\section{Effect of labor wages on the number of labors}

Based on data every year there is an increase in labor wages with a percentage of 7 to $13 \%$, so this has an impact on the amount of costs to be incurred by the company. The rising labor costs have an impact on the logistics costs of the company which ultimately makes the competitiveness of the company's products inferior to similar companies, this makes the company change the pattern of work and use of labor by making new agreements with Stevedoring (PBM) and KTKBM, calculation of labor needs that were previously per crane changed to per ship and adjusted to the needs on the basis of consideration the more labors used the greater the cost of overtime incentives incurred by the company. This is because outside of the tariff per ton (work output) the company is also required to pay overtime incentives to labors in accordance with the labor quota agreed in the work contract between the company and the stevedoring company (PBM) which coordinates the labors.

Table 7 : Agreement on the Number of Labors Worked

\begin{tabular}{|c|l|c|c|c|c|}
\hline \multirow{2}{*}{ No. } & \multirow{2}{*}{ Cargo } & \multicolumn{2}{|c|}{ Before 2016 } & \multicolumn{2}{c|}{ After 2016 } \\
\cline { 3 - 7 } & & Total & Unit & Total & Unit \\
\hline 1 & Pulp & 11 & per Derek/Crane & 11 & per Barge/Vessel \\
\hline 2 & Paper & 7 & per Derek/Crane & 7 & per Barge/Vessel \\
\hline 3 & Container & 7 & per Derek/Crane & 7 & per Barge/Vessel \\
\hline 4 & $\begin{array}{l}\text { Bag } \\
\text { Cargo }\end{array}$ & 11 & per Derek/Crane & 11 & per Barge/Vessel \\
\hline 5 & $\begin{array}{l}\text { Spare } \\
\text { part }\end{array}$ & 11 & per Derek/Crane & 11 & per Barge/Vessel \\
\hline
\end{tabular}

Source: PT. IKPP, 2019

Based on the data above it has been proven that wages do have a negative and significant effect on labor needs, because with an increase in labor rates the company will try to reduce the demand for the number of labors in the hope that the costs incurred for labor costs will be reduced or at least the same as before, this is because companies must keep their product prices competitive in the market. This study supports previous research conducted by Indarti (2016), Nababan (2017), Ningsih (2015), and Prastyaningsih (2016) who say that wages have a negative and significant effect on labor demand because many industries use capital-intensive technology for their production processes. This condition occurs when wages rise with the assumption that prices of fixed capital goods. Decreasing the number of labors due to the replacement of machines so that the industry reduces labor. This is also consistent with the theory put forward by Sumarsono (2006) which says that an increase in the wage rate in the long run will be responded by companies with adjustments to the inputs used. The company will use capital-intensive technology for its production process and replace labor with capital goods such as machinery and others. This condition occurs when the wage level rises assuming the prices of other capital goods are fixed. The decrease in the use of the amount of labor needed because of the replacement or additional use of machines is called the substitution effect of labor or substitution effect (capital intensive).

However, this is different or contrary to research conducted by Ismail (2013) and Chusna (2013) where their research shows that for developing industries in developing countries and wage levels have a positive effect on labor demand, which means the higher wage levels will more and more labors want to work. This condition is different from what happened in Perawang Port due to the market orientation of 
PT. Indah Kiat is an export and labor costs are one of the cost components that are a burden in product competition in the market, the greater the logistics costs incurred by the company, the higher the price of the product and the impact of the product being sold is unable to compete in the market.

\section{CONCLUSION}

Based on the results of research and discussion, it can be concluded that:

1. Partially from the 3 variables tested are shipment containers, investment and wages, which have a significant effect on labor demand is wages. With the increase in wages, labor demand will decrease, this is because companies will try to keep their products competitive in the market by reducing costs.

2. Container shipment in the long run has a negative impact on the demand for labor.

3. The determination of the number of labors employed is influenced by the following things:
a. Types of goods that are unloaded / loaded.
b. The amount of wages paid.
c. Agreement between Labor Organization (KTKBM) with PBM (Stevedoring Company) or Customer.
d. Type of Crane used during loading or unloading activities.
e. Law, regulation and government policy.

4. The influence of Container Shipment, Investment in Mechanical Equipment and Labor Wages together has a significant effect on the number of labors with a significance of $89 \%$.

5. IKPP Jetty is private jetty so loading and unloading speed is very important and affects to the efficiency and productivity of the company

\section{SUGGESTION}

Based on the results of the analysis and conclusions previously described, suggestions that can be made are as follows :

1. From the labor side, it is necessary to streamline the organization by no longer extending / replacing personnel who have entered retirement age (Joint Decree of the Director General of Sea Transportation et al, 2011) and changing mindsets to try to increase their skills not only as unskilled laborers but also have to think to be able to find other alternatives in accordance with the development of the logistics world.

2. For cost efficiency, time and customer satisfaction, container shipping from the company side is very effective and has the potential to continue to be developed, and is supported by investment in mechanical devices intended for container loading and unloading..

3. To keep economic conditions conducive, the company is advised to:

a. Conduct training - creative economy training for the surrounding community and labors to be able to open their own business fields and no longer depend on their work as loading and unloading labors.

b. Provide assistance directly to business groups or communities in need

c. Approach and foster community with community development programs

d. Provide job opportunities according to their expertise and fields in the company.. 


\section{BIBLIOGRAPHY}

[1]. Arfida BR, 2003, Human Resource Economics. (Jakarta: Ghalia Indonesia)

[2].Bureau of Law and Foreign Cooperation Secretariat General of the Ministry of Transportation, 2008. Law of the Republic of Indonesia, Number 17 of 2008 concerning Shipping

[3].Chusna, Arifatul, 2013. The Influence of the Growth Rate of the Industrial Sector, Investment and Wages Against the Absorption of Industrial Sector Labors in Central Java Province 1980-2011, Journal. Faculty of Economics, Semarang State University. ISSN 2252-6889.

[4].Divianto, The Effect of Wages, Capital, Productivity, and Technology on Labor Absorption in Small and Medium Enterprises in Palembang City (Case Study of Printing Business), Journal of Economic Accounting of Sriwijaya Polytechnic Vol. 4 January 2014.

[5].El-Sahli, Zouheir and Richard Upward, 2017, Off theWaterfront: The Long-Run Impactof Technological Changeon Dockworkers, British Journal of Industrial Relations

[6]Evergreen Marine Corp, 2019, Container Specification, akses 5 Desember 2019, <https://www.evergreen-marine.com/tei1/jsp/TEI1_Containers.jsp $>$

[7].Faisal, Noor, Hendry, 2007. Managerial Economics. PT. Raja Grafindo Persada, Jakarta

[8].Hasibuan, Malayu S.P. 2012. Human Resources Management Revised Edition. Jakarta. PT. Earth Literacy.

[9].Indarti, Titis Wahyu Ryan, 2016, Analysis of Factors Affecting the Demand and Supply of Industrial Sector Labors in Java in 2004-2015. Journal entry. IPB Faculty of Economics, volume3

[10].Ismail, Rahmah, Zulkifly Osman, Ferayuliani Yuliyusman, Analysis of Determination of Demand for Firm Labors in Malaysia, Faculty of Economics and Management of the Malaysian National University, PROSIDING OF PERKEM VIII, Volume 2 (2013) 888 - 897, ISSN: 2231-962X

[11].Joint Decree of the Director General of Sea Transportation, the Director General of Labor Inspection Development and the Deputy for Institutional Cooperatives and Small and Medium Enterprises, 2011, concerning the Development and Arrangement of Unloaded Manpower Cooperatives (TKBM) at the Port.

[12].Kusumastanto, Tridoyo 2018, Maritime Paradigm, Maritime Economic and Learning Target, .IPB /PKSPL -DGST BUP XXIII

[13].Lasse D.A 2007, Equipment Management, Operational and Maintenance Aspects. Jakarta. NIKA

[14].Lasse D.A 2009, Cargo Management, Supply Chain Activities in the Port Area. Jakarta, NIKA

[15].Mangkunegara Anwar Prabu, 2001. Management of Corporate Human Resources. Bandung. PT. Remaja Rosdakarya. 
[16].Monaco, Kristen \& Lindy Olsson 2005. Labor at the Ports: A Comparison of the ILA and ILWU, Department of Economics California State University Long Beach 1250 Bellflower Blvd.Long Beach

[17].Nababan, Tongam Sihol, The Effect of Number of Industrial Enterprises, Value of Input, Value of Output, And Regional Minimum Wage on Labor Demand Indonesia : An Empirical Study on Micro Industrial Enterprises, Faculty of Economic, University of HKBP Nommensen, Medan Indonesia, 2017. MPRA Paper No. 79680.

[18].Nacrhowi. 2004. Effect of Economic Structure on Sectoral Labor Absorption: Analysis of Demometric Models in 30 Provinces in 9 Sectors in Indonesia. Indonesian Journal of Economics and Development. Vol. V.

[19].Ningsih, Ni Made Chaya, Effect of Capital and Wage Levels on Production Value and Labor Absorption in the Silver Craft Industry, Faculty of Economics and Business, Udayana University. Journal of Applied Quantitative Economics Vo. 8 No.1, 2015

[20].Prastyaningsih, Arum, Analysis of labor absorption in large and medium industrial sectors such as the residency of Surakarta in 2006-2013, Faculty of Economics and Business, Muhamadiyah University of Surakarta, 2016

[21].Putra, Riky Eka, The Effect of Investment Value, Wage Value, and Production Value on Labor Absorption in Furniture Industry in Pedurungan District, Semarang City, Department of Development Economics, Faculty of Economics, Semarang State University, Indonesia, 2012

[22].Randy Mahendra, 2014, The Influence of Industry Number and Production Capacity on Manpower Absorption in Blitar City, Journal of the Faculty of Economics and Business Universitas Brawijaya, volume 1. October 2014

[23].Santoso, Roekhedi Priyo, 2012. Economics of Human Resources and Employment, UPP STIM YKPN Yogyakarta.

[24].Sudarmo, Sudjanadi Tjipto, 2018, Port Business Strategy and Development, Best Practice 6th Edition"Global Competition Perspective .IPB /PKSPL -DGST BUP XXIII

[25].Sukirno, Sadono. 2011. Introduction to Macroeconomics Theory, Third Edition. Jakarta: Rajawali Press

[26].Sukirno, Sadono. 2014. Microeconomics Introduction Theory, Third Edition. Jakarta: Rajarafindo Persada

[27].Sumarsono, 2006. Economics of Human Resource Management and Employment. Graha Science. Yogyakarta

[28].Tomlinson, Jhon, 2009. History and Impact of the Intermodal Shipping Container. Pratt Institute For LIS 654-05/Carrie Bickner.

[29].Labor Law No. 13 of 2003, State Gazette of the Republic of Indonesia of 2003 Number 39 
[30].UNCTADstat, 2019, United Nations Conference on Trade and Development Palais des Nations, 814, Av. de la Paix, 1211 Geneva 10 Switzerland, accessed December 52019 . < https://unctadstat.unctad.org/EN/>. 